\title{
More Democracy Is Not Better Democracy: Cain's Case for Reform Pluralism
}

\author{
Piers Norris Turner
}

\section{INTRODUCTION}

A PERSISTENT WORRY about real-world democracies is the extent to which they allow some individuals to exert disproportionate influence on electoral and legislative processes, whether because of wealth, gender, race, religion, education, or other considerations. Inequalities in political influence seem inconsistent with the equal concern and respect that many political theorists now argue constitutes the intrinsic value of democracy and legitimizes coercion by the state. In order to satisfy the demands of democratic legitimacy, then, it seems we must work to eradicate inequalities of political influence wherever possible.

Against this, democratic "pluralists" have long argued that no real-world democracy can deliver on such ideals of democratic legitimacy, and that the attempt to do so will actually undermine our valuable, though imperfect, existing democratic institutions. ${ }^{1}$ The underlying problem is that politics is always going to be an arena in which different organized groups assert their interests against each other, with sometimes messy results. Pluralists agree with Madison that "that the causes of faction cannot be removed, and that relief is only to be sought in the means of controlling its effects." 2 They thus argue that while conflict cannot be eradicated, it can be managed by a series of institutional checks and balances that distribute power and provide con-

Piers Norris Turner is an assistant professor in the Department of Philosophy at The Ohio State University in Columbus, $\mathrm{OH}$. The author is grateful to Bruce Cain, Ned Foley, Eric MacGilvray, and Michael Neblo for comments on an earlier draft of this essay. It was presented at a 2013 symposium on Cain's book, Democracy More or Less: America's Political Reform Quandary, organized by the Democracy Studies Center at The Ohio State University. strained competitive fora. Basic democratic institutions and procedures, including periodic elections as well as freedoms of speech and association, remain important in the pluralist picture. But pluralists argue that on any realistic democratic model, individuals will have a voice largely through organized groups representing their interests. Managed well, the conflict of interests can prevent any one interest group from dominating others over the long-term. But any hopes of achieving democratic ideals like equality of political influence will be thwarted by the realities of political life.

In Democracy More or Less: America's Political Reform Quandary, Bruce Cain offers a sophisticated version of the Madisonian position, which he calls "reform pluralism." 3 Like other pluralists, he argues that democratic legitimacy should not be understood in terms of the achievement of some democratic ideal but only in terms of satisfying basic democratic accountability requirements. This is partly for theoretical reasons having to do with the difficulty of articulating a single coherent democratic ideal, and partly for the practical reason that most significant reform efforts are bound to have perverse effects on the democratic system itself. Underlying these claims is a deep pessimism about what it is reasonable to expect of the average citizen in terms of public concern, intelligence, and expertise. In slogan form, Cain concludes that more democracy is not (likely to be) better democracy.

\footnotetext{
${ }^{1}$ See e.g., Robert Dahl, A Preface to Democratic Theory (Chicago: University of Chicago Press, 1956) and Who Governs (New Haven: Yale University Press, 1961).

${ }^{2}$ James Madison, Federalist, No. 10.

${ }^{3}$ Bruce Cain, Democracy More or Less: America's Political Reform Quandary (Cambridge: Cambridge University Press, forthcoming), 20ff. All in-text citations are to this work.
} 
His main practical conclusion is thus a skeptical one. Despite widespread frustration about the American political system, he argues, most ambitious democratic reform efforts are either ill conceived or anyway bound to fail.

In these comments I want to explore the framework underlying the "pluralist" approach in hopes of making clearer how one might resist Cain's skeptical practical conclusion. In section 2, I present in more detail Cain's reform pluralist argument for a set of mid-level practical principles. In section 3, I argue that, with regard to what might count as better democracy for Cain, the most natural framing of his argument is that of democratic instrumentalism. Instrumentalists tend to share Cain's view that the best form of democracy is not one that perfectly embodies an abstract democratic ideal, but one that does the best in actually promoting the public good. In section 4, however, I suggest that the instrumentalist should not accept Cain's skeptical conclusion, despite the cogency of his critique of certain overly idealistic reform efforts. His arguments against idealistic overreach do not undermine the possibility of significant improvements to our democratic political system, especially in light of his own recognition of significant improvements in the past.

\section{REFORM PLURALISM}

Cain begins with the observation that Americans are deeply dissatisfied with the state of their political system. But he warns against "corruption confusion," arguing that there is relatively little direct material corruption in the U.S. political system (162-163). Rather, the corruption that underlies our dissatisfaction is the "democratic distortion" resulting from the institutional perversion of democratic aims or the systematic undermining of democratic principles (164). For many reformers-whom Cain calls "populists"-the worry about democratic distortion is grounded in the arguably quintessential democratic value, mentioned already, that all individuals should have equal influence over the political process: "The populist reformer aspires to apply the 'one person, one vote' equality principle across all dimensions of political influence, empowering individual citizens with equal opportunities to contribute to campaigns, acquire information from the government, observe decisions and remove officials they do not like" (7). On this view, as long as some of us have more influence than others, there is reason for democratic reform. The resulting practical impulse among populists, which Cain labels the "democratic imperative," is toward "more opportunities for citizens to observe, participate in and control their government's actions," approaching something like a plebiscitary democracy of unmediated majoritarian control over political decisions (7).

The problem, Cain argues, is that the populist response to democratic dissatisfaction is plagued by theoretical and practical difficulties, and much of the book pursues the critical task of showing how the populist approach fails. Among the theoretical difficulties is identifying what counts as democratic distortion in the first place. For instance, there are many compelling conceptions of fairness, procedural and substantive, that are not all capable of being instantiated together. Why should equality of influence be the unique democratic fairness concern when majoritarian procedures may threaten a tyranny of the majority? Similarly, the populist drive toward greater participation and transparency must be balanced against other democratic values, such as deliberation and the effective representation of interests. There is no single weighting of these goods that is obviously most democratic.

Despite these difficulties, Cain accepts that historical democratic developments have established a universally recognized threshold or "lower boundary" (18) for basic democratic accountability, constituted by universal suffrage, periodic elections, and the provision of certain basic rights including freedom of speech and freedom of association. These are settled matters and, for the reform pluralist, meeting these threshold conditions is sufficient for democratic legitimacy. The challenge facing democratic reformers is whether any reforms are required above this democratic legitimacy threshold, in what Cain calls the "democratic interval" (18). Partly because of the theoretical difficulties just described, however, reform pluralists are skeptical about any further specification of what democratic legitimacy requires. The pluralist rather embraces the thought that theoretical differences are themselves subject to political compromise, with democratic developments worked out by interest groups themselves in real time. This may leave our political system looking like an awkward or even incoherent balancing of various democratic 
values - and it makes the question of democratic distortion much more complicated-but that is all that we can reasonably expect or want. As a result, reformers should not buy into any one ideal of democracy as a blueprint for reform efforts.

Cain's skepticism carries over to practical matters, where he argues that the American political system has structural constraints that severely limit the short-term reform agenda, including a constitution that is near-impossible to amend and which enshrines certain representative institutions anathema to majoritarian impulses, as well as a Supreme Court that has upheld a strong view on First Amendment liberties and campaign spending despite the resulting inequality of influence on the political process. This last constraint forces us to accept that moneyed interests will not simply be regulated away in favor of the populist ideal of perfect equality of influence.

Cain criticizes populist reform efforts in two main ways: they either undermine their own stated goals or they succeed only by undermining some other equally important democratic value. Thus, for example: in trying to maximize citizen participation, reformers may actually overburden and turn off citizens; or in focusing too much on transparency, reformers may damage democratic deliberation that requires some breathing room; or in establishing an initiative process to promote direct democracy, reformers may simply provide special interests a new tool to control and exploit the political system; or in setting up citizen oversight bodies, reformers may simply create a new delegation that must be held accountable and is susceptible to the same interests as the previous arrangement-Cain calls this last problem the "delegation paradox" (7-9).

But the general, underlying practical problem with populist proposals is that they expect too much of average citizens and their representatives: "the questions that are not asked frequently enough, despite decades of empirical research on this topic [citations omitted], are whether individual citizens have the resources, motivation and capacity to undertake these new civic opportunities, and if not, what does this mean for the design of effective reforms?" (7). We cannot reasonably expect the electorate to consistently exhibit the intelligence and publicspiritedness necessary to make the populists' ideal participatory systems work. Nor can we expect our representatives to be impartial judges. Human beings will always suffer from cognitive and sym- pathetic deficiencies. This perhaps explains why Cain makes no mention of long-term reform possibilities through public education. He does not seriously entertain the thought that the quality of our democracy might improve over time by improving the qualities of the citizens themselves.

Unlike the populist, Cain argues that we must operate within our historical, Madisonian system designed to balance coalitions of competing interests through a variety of checks and balances. In trying to accommodate the "democratic imperative," then, the pluralist aims only to "make the proxy representation of citizens by interest groups, nonprofits, political parties and other intermediaries as fair and effective as possible" (6). Fortunately, the pluralist argues, our Madisonian system of representative and divided government offers a pragmatic approach to democratic accountability that meets the democratic legitimacy threshold by balancing those coalitions of interest groups without giving any of them a permanent institutional advantage. Bearing in mind the constraints of the American democratic system, Cain finally endorses a handful of minor, incremental reforms, including: ensuring that all citizens' votes are treated equally at the ballot box, with uniform rules governing how votes are cast and counted; introducing rules for semi-disclosure of campaign donations in which identities are not revealed but other relevant voter data might be made public so that citizens could see who is behind candidates and policy proposals; and rather than limiting campaign spending, trying to find ways to provide public funding to candidates that otherwise could not compete with privately funded campaigns.

With apologies to the nuances of Cain's arguments, reform pluralism can be summarized in four claims. (1) Certain threshold democratic accountability features are necessary and sufficient for political legitimacy. (2) Any effort to improve a democracy above that threshold by single-mindedly reforming one aspect of the democratic system-in particular, increased citizen participation-is bound to have perverse consequences. (3) The fact of citizens' cognitive and motivational limitations entails that any democratic reforms requiring people to participate significantly in legislation or governance are bound to fail. (4) Reform efforts should be limited to (a) protecting the basic democratic threshold features and (b) securing a fair playing field for competing interest groups in society. 


\section{THREE FRAMEWORKS FOR PLURALISM}

In evaluating reform pluralism, I want to focus on how the lower boundary-the basic democratic legitimacy threshold-is justified. Cain acknowledges that the lower boundary of democratic accountability has changed over time:

In the earliest periods of American history, the electorate did not include women, minorities and younger voters. Senators were selected by state legislatures, and presidential nominations were controlled by party caucuses and elected officials. Citizens had no freedom of information rights or open meeting laws to assist them in figuring out what the government had done or was planning to do. It was truly a minimal democracy, not one that would be deemed sufficiently democratic today. (14)

He adds that the "boundary between democracy and nondemocracy is...dynamic over time" (14).

What should we make of these claims? On one hand, Cain seems to allow that the basic democratic legitimacy threshold has changed over time, and for the better. On the other hand, we saw earlier his argument that there is little reason to expect future reform efforts to lead to any significant improvements in the quality of our democracy.

Presumably, however, earlier changes to the democratic threshold resulted from reform efforts that were pursued when the basic elements of the pluralist picture-competing interest groups and cognitively and motivationally limited citizens-were also in effect. It is important to appreciate that Cain does not provide a general argument for why improvements in the basic democratic threshold are less likely now than before. He argues effectively for the much more limited claim that specific reform efforts inspired by single-minded populism are likely to have perverse effects. But, in order to secure the pluralist's reform skepticism, he needs to show that the theoretical and practical difficulties facing less single-minded and idealistic reform efforts are greater today than in the past.

Consider three simplified frameworks that accommodate both Cain's acceptance of the current democratic legitimacy threshold and his skepticism about improvements beyond it. One natural way of making sense of the pluralist approach is to regard it as a form of political realism that recognizes a widespread commitment to basic democratic accountability mechanisms but rejects the moral impulse toward reform. Call this democratic realism. The democratic realist accepts the significance of the democratic threshold for providing stability and the balance of interests, and argues that political reformers must respect the sociological fact that there is a near-universal acceptance of those legitimacy conditions in Western democracies. But the realist does not emphasize the moral value of that threshold (or of potential improvements to it), and resists reforms that might threaten the stability it provides.

Though some of what Cain writes seems to be in the democratic realist mode, it is doubtful that he is a thoroughgoing realist. Certainly, the pluralist's disdain for ideal theory sometimes evokes the realist's antipathy to idealistic reformers. And like the realist, Cain does not provide much in the way of guiding moral principles. But his acceptance of the democratic threshold does seem to be a moral commitment, and not merely an acknowledgment of sociological fact.

A second way of making sense of the pluralist approach would be to adopt a public reason framework in which the legitimacy of state coercion is understood in terms of what can be justified to all reasonable citizens. ${ }^{4}$ On this view, the democratic threshold would be defined by whatever is publicly justified and it may change over time. But the public reason pluralist-who is skeptical of political reform-could also argue that advocating for changes to the status quo at any given time might endanger the currently publicly justified order. The democratic threshold recognized at any particular time would have moral significance in virtue of its being justified to all reasonable citizens. But the public reason pluralist might resist, on related moral grounds, any changes that would threaten the publicly justified order. ${ }^{5}$

\footnotetext{
${ }^{4}$ See, e.g., John Rawls, Political Liberalism (New York: Columbia University Press, 1993).

${ }^{5}$ Gerald Gaus argues that, given the great value of an equilibrium on social rules, there must be a strong bias toward the status quo in any realistic public reason theory. See Gerald F. Gaus, The Order of Public Reason (Cambridge: Cambridge University Press, 2011).
} 
This kind of view has its attractions, but I think it also does not capture Cain's own thinking. Instead, he writes, "Democracies must produce good outcomes for their citizens in a utilitarian sense. To be sure, an election is an imperfect welfare calculus and tool for promoting governance, but it is the foundation of democratic design" (15). Like Madison, Cain seems to justify his claims ultimately in terms of what conduces to the public good.

The third way of making sense of Cain's pluralism, then, is by appeal to democratic instrumentalism, according to which democratic institutions have value only insofar as they conduce to the public good (suitably characterized). An advantage of this account is that it neatly explains Cain's basic difference with populist reformers. Unlike the populist, the instrumentalist is not ultimately concerned with making our system perfectly democratic (along some dimension), but with making our imperfect democracy as effective as possible in promoting the public good. On an instrumentalist view, Cain argues for skeptical practical conclusions because theoretical and practical difficulties make it unlikely that populist democratic reforms will do better than the Madisonian system in promoting the good. We may need to tinker with our democracy to keep it running smoothly within its Madisonian limits, and of course we should guard against any major threats to basic democratic legitimacy, but that is about it. Trying to do more than that, guided by some democratic ideal, is bound to lead to worse outcomes.

Let us assume that even a more optimistic instrumentalist would agree with Cain that those who aim to maximize democracy - and who hold that government legitimacy hangs on meeting idealized democratic conditions-are mistaken. More democracy need not always be better democracy, and democratic legitimacy should not be tied to the achievement of some maximal populist ideal. But setting Cain's pluralism in an instrumentalist setting also opens it up to a clear challenge from the optimist. For if better democracy is cashed out in terms of conduciveness to the public good, then the optimist may argue that Cain has failed to make the case that we can do no better-above the current democratic threshold conditions-than just to tinker with our Madisonian system. In rejecting the single-minded pursuit of populist aims, Cain has not shown that piecemeal and balanced-but still significant-democratic changes could not raise the democratic threshold in the future.

\section{ROOM FOR REFORM}

In the context of democratic instrumentalism, the question of whether Cain's pessimism about democratic reform is justified is an empirical one. He argues convincingly that in the near term there are constitutional constraints on what can be achieved:

[R]eform occurs within a general constitutional framework that is rarely challenged and nearly impossible to change at the federal level. Politically feasible reforms necessarily take the separation of powers, federalism, permeable bureaucracy, court review, strong First Amendment tradition, political professionalism, and suspicion of power as givens. To do otherwise is politically naïve and utopian. But the decision to do what is possible-a second-best strategy-has significant consequences for the form and effectiveness of reform efforts. (39)

But it is striking that rather than call for longterm reform efforts to amend the constitution or to educate the citizenry or to develop new democratic institutions, he simply concludes that we must work within those constraints indefinitely. With a long view, an optimistic instrumentalist has room to argue that it is worth attempting a variety of democratic experiments to see what improvements for posterity might result. These efforts must be balanced rather than single-minded, and most experiments will fail, but Cain seems to move too quickly from the failure of populist over-idealization and single-mindedness to the claim that even piecemeal reforms are unlikely ever to constitute significant improvements over the Madisonian system. For instance, the fact that maximizing citizen participation across the political system will have perverse consequences is not an argument against increasing citizen participation here and there, and the fact that we can never fully rein in the influence of moneyed interests on politics is not an argument against partial measures to change incentives. Over time these changes might have significant effects on the quality of our democracy as an instrument to promote the public good.

It seems that pluralism-like political realismoverreacts to utopian thinking with unnecessary hard-headedness. Many earlier reformers were also overly idealistic —one need only think of the many experimental communities of the late 
nineteenth century - but some of their efforts over time resulted in real improvements that were successfully adopted within the existing political system. It is certainly difficult to predict which reform efforts might lead to further improvements. Perhaps most of them will fail. But I do not see any less reason now than before to believe that some of them could lead to important improvements in our democratic system.

Evaluating the success of these democratic experiments presents its own challenge. But note that, in the context of democratic instrumentalism, we are no longer trying to measure how democratic a system is-with all the theoretical difficulties Cain highlights - but rather how well a political system promotes the public good. Recent years have seen a rise in the development of indices to measure effectively the average quality of life or happiness of citizens in different countries. These provide a foothold to evaluate different political systems above the democratic threshold. ${ }^{6}$

Cain's long-term skepticism hinges on his view of human limitations. That is what fundamentally seems to stand in the way of his moving away from the Madisonian vision. On his view, any more rationalistic picture of democratic processes is bound to demand too much either of our cognitive abilities or of our capacity for impartial judgment. Such rationalistic reforms would thus tend toward worse outcomes than the messy but workable give-and-take of the current system.

But I am optimistic that even though people are not perfectible we are still improvable and that changes in social conditions over time may do a great deal to foster an ideal of citizenship in which individuals are expected to have a more disinterested concern for others. In this respect, it is interesting how far Cain has shifted away from his instrumentalist predecessor, John Stuart Mill. Mill believed that over time individuals could be improved through education and could develop pub- lic spirit to a much greater extent than they exhibit currently. This belief made it possible to imagine a democratic system relying to some degree on citizens' impartial regard for the public good, rather than for their own self-interest. ${ }^{7}$ As a result, he remained open to a host of practical democratic proposals.

Mill may have been too optimistic in this respect. But the long-term question for our reform efforts now is not whether there are limits to human moral and intellectual improvement-there surely are-but whether we have reached them yet. Given historical social improvements, which Cain himself acknowledges, I believe we still have strong reason to engage with the difficult long-term project of developing a better culture of democratic citizenship.

\section{CONCLUSION}

By adopting a democratic instrumentalist framework, Cain is able to get critical leverage on populists focused exclusively on making our democracy as democratic as possible. If we focus too much on having more rather than better democracy, we run into significant theoretical and practical difficulties. Cain's book is invaluable for making this case as comprehensively as one could hope, based on masses of empirical evidence. But the instrumentalist account of better democracy also gives us reason to believe that significant reform efforts remain worth pursuing, for the simple reason that some of them have worked in the past.

Address correspondence to:

Piers Norris Turner

Department of Philosophy

The Ohio State University

230 N. Oval Mall

Columbus, $\mathrm{OH} 43210$

E-mail: turner.894@osu.edu

\footnotetext{
${ }^{6}$ One instructive recent attempt to evaluate democracies by such indices is Benjamin Radclifff, The Political Economy of Human Happiness (Cambridge: Cambridge University Press, 2013). We should be open to the thought that democratic experiments around the world might suggest long-term possibilities for our own democracy.

${ }^{7}$ John Stuart Mill, Considerations on Representative Government, Vol. XIX of The Collected Works of John Stuart Mill, ed. J.M. Robson (Toronto: Toronto University Press, 1861), 371-577.
} 